\title{
Assessment of the potential for dredged material dispersal from dumping sites in the Gulf of Gdańsk
}

\author{
Witold Cieślikiewicz $^{1}$ (D) - Aleksandra Dudkowska ${ }^{1} \cdot$ Gabriela Gic-Grusza $^{1}$ • Jan Jędrasik ${ }^{1}$
}

Received: 21 November 2017 / Accepted: 15 June 2018 / Published online: 25 June 2018

(C) The Author(s) 2018

\begin{abstract}
Purpose Environment-friendly management of sites used for disposal of locally generated sedimentary material involves designation of an optimal dumping site location which will render the dredged material re-usable for beneficial purposes. The objective of this research was to determine whether wind, waves, and currents can induce transport of sediment from offshore dumping sites located at intermediate depths in the southern Baltic.

Materials and methods The problem was addressed by exploring potential sediment transport from two sites located in the Gulf of Gdańsk at depths of about $20 \mathrm{~m}$. A total of 29 combinations of hydrodynamic variables, representing the most extreme possible situations in the area, including eight theoretical uniform wind fields over the entire Baltic Sea from the W, NW, N, NE, E, SE, S, and SW sectors, the wind speed of $30 \mathrm{~m} \mathrm{~s}^{-1}$, as well as 21 historical extreme storms, retrieved from the HIPOCAS project database, were used.

Results and discussion The bottom velocities resulting from waves and currents at the dumping sites considered were computed using wave models (WAM, SWAN) and the M3D hydrodynamic model (based on the POM model). To estimate the velocities critical for bedload transport, formulae developed by Soulsby (1997) and Sawamoto and Yamashita (Proc Coastal Sediments 87:415-423, 1987) were used. The volumetric bedload transport was computed based on Meyer-Peter and Müller (1948). The model simulations demonstrated that, for the storm conditions analyzed, the current velocity in the area of the two dumping sites would be so low that it would practically not affect the magnitude of the bottom sediment transport. Thus, the resultant volume of bedload transported would be equal to that generated by the wave action. For the heaviest historical storm, the maximum transport is about $3 \times 10^{-5} \mathrm{~m}^{2} \mathrm{~s}^{-1}$.

Conclusions Under conditions of theoretical storms, the bottom orbital velocities would be higher and the resultant sediment transport would reach almost $7 \times 10^{-5} \mathrm{~m}^{2} \mathrm{~s}^{-1}$ for northerly winds. However, this value is still very low compared with the volume of sediment being dumped. The findings of this study may prove useful in designation of future dumping sites.
\end{abstract}

Keywords Bedload transport · Coastal hydrodynamics $\cdot$ Coastal zone $\cdot$ Gulf of Gdańsk · Landfills

\section{Introduction}

Modernizing sea harbors is associated with waterway and basin dredging and the resultant need to manage the dredged material. Storage of the excavated material for which there is no use is an issue of concern for the coastal zone management worldwide (e.g., Van Dolah et al. 1984). Selection of

Responsible editor: Vito Ferro

Witold Cieślikiewicz cies1@ug.edu.pl

1 Institute of Oceanography, University of Gdańsk, Al. Piłsudskiego 46, 81-378 Gdynia, Poland appropriate locations for off-shore dumping has to involve considerations regarding the depth of the natural bottom, allowing for deposition of a considerable amount of the excavated material, as well as the relevant hydrodynamic parameters, i.e., wave action, currents, possible shipping difficulties, and feasibility of site management and monitoring. The environment-friendly approach calls for the re-use of the excavated material in shore-protection measures (e.g., artificial shore nourishment) rather than just leaving it in the sea (Staniszewska and Boniecka 2015). Thus, the dumping site selection should consider the potential dispersal of the material dumped.

Extended studies on sediment transport in the southern Baltic Sea were carried out in the Pomeranian Bay (Christiansen et al. 2002; Emeis et al. 2002; Kuhrts et al. 
2004), in the Gulf of Gdańsk (Ostrowski et al. 2010; GicGrusza and Dudkowska 2017), and along the Lithuanian coast (Pupienis and Jankowski 2006). Most of those studies involved application of circulation and wave models as well as sediment transport and bottom boundary layer ones. The first research mentioned above was based on measurements of sediment suspension in natural scale (SW Baltic Sea). Ostrowski et al. (2010) determined the offshore wave climate using the numerical prognostic wave model (The Third-Generation Wave Model https:/github.com/mywave/WAM) (WAM) and then used the UNIBEST-LT numerical program to calculate net sand transport on the cross-shore profiles at eight selected coastal locations in the eastern part of the Gulf of Gdańsk. To estimate the sediment transport rate, Pupienis and Jankowski (2006) calculated the critical shear stress velocity based on the hydrodynamic data derived from the Princeton Ocean Model (homepage: http://www.ccpo.odu.edu/POMWEB/; user guide: http://www.ccpo.odu.edu/POMWEB/UG.10-2002.pdf) (POM) using the code of Blumberg and Mellor (1987). Recently, Gic-Grusza and Dudkowska (2017) determined wave-induced shear stress and resulting sediment transport in the Gulf of Gdańsk. It should, however, be emphasized that most of the knowledge on sediment movement in the area of interest is based on qualitative findings (Harff et al. 2017). Reliable in situ measurements of bottom velocity and sediment transport, especially in the storm conditions analyzed in this study, are particularly difficult and thus observed values of those parameters are very rare for the Gulf of Gdańsk basin.

Identification of areas with high and low shear stress at the bottom made it possible to designate sites amenable for dumping and those likely to be affected by re-suspension and sediment transport, but more detailed studies are required to define an optimal location of a dumping site.

According to the HELCOM (2015) database, ${ }^{1}$ there are 14 dumping sites in the southern Baltic Sea; three of them are located in the Gulf of Gdańsk and Puck Buy, at depths of 30 and 55-60 m, respectively (Fig. 1). Potential additional locations could be placed closer to the shore, at shallower depths (18-22 m), on the slope of the Gulf of Gdańsk (Fig. 1). In this work, we considered the appropriateness of those locations in terms of their amenability to the transport of the dumped material induced by hydrodynamic conditions. To this end, we checked whether the most extreme hydrodynamic conditions possible would disperse the deposit dumped. Sediment transport in the areas of dumping can occur once critical values of individual grain movement speed and sheet flow movement have been exceeded. We asked whether the most extreme hydrodynamic conditions possible would induce the bottom orbital velocity to exceed the critical level. To answer this

\footnotetext{
${ }^{1}$ The database covers dumping site areas reported by the HELCOM Contracting Parties according to the HELCOM recommendations for the reporting period 2011-2015.
}

question, we modeled the Gulf of Gdańsk hydrodynamics (wind-generated waves and currents) under an assumption of the most extreme weather conditions possible. It appears that sediment transport under such conditions is possible, but the magnitude of transport would be so low that the amount of lost (dispersed) material would be negligible. Since there is a lack of observational data on sediment transport in the Gulf of Gdańsk, our findings - based on the results of widely implemented and well-validated numerical models - provide the first insight into the dispersion pattern of the area of interest.

\section{Materials and methods}

\subsection{Study area, bathymetry, and sedimentary environment}

Two possible dumping sites were designated in the western part of the Gulf of Gdańsk (see Fig. 1). Sites 1 and 2 are located about 10 and $2-8 \mathrm{~km}$ off the shore, respectively, $5 \mathrm{~km}$ away from each other, and at depths of $18-22 \mathrm{~m}$. Sites 1 and 2 cover 2.58 and $3.56 \mathrm{~km}^{2}$, respectively. Coordinates of the sites' corners are given in Table 1. The dumping material volume assumed is about $6 \times 10^{6} \mathrm{~m}^{3}$; this amount would be expected to change the bathymetry of the sites considered by shallowing them by about $1 \mathrm{~m}$.

The Baltic Sea bathymetry data provided by the Institut für Ostseeforschung in Warnemünde (IOW) (Seifert and Kayser 1995) were used as an input to the Wave Forecast Model WAM. The data were thoroughly examined and adapted to the wave model requirements. For wave modeling of the Gulf of Gdańsk, the bathymetric data provided by the Naval Hydrographic Office, digitalized by the Maritime Institute in Gdańsk, were used.

The 1:200000 Geological Map of the Baltic Sea Bottom (Mojski 1988-1995) shows the bottom of coastal areas in the vicinity of the potential dumping sites considered here to be covered mostly by fine- and medium-grained sands. As shown by research conducted by the Department of Marine Geology, Polish Geological Institute in Gdańsk (PIG-PIB 2012), also most of the approach channel to the port of Gdańsk, which is one of the biggest harbors in the area, is covered by sands, predominantly mostly fine-grained, moderately well, and well sorted. The median grain size $D_{50}$ varies from 0.18 to $0.88 \mathrm{~mm}$; the amount of sediment with $D_{50}<0.2 \mathrm{~mm}$ being equal to the amount of sands with $D_{50}>0.2 \mathrm{~mm}$. In this study, we assumed the dumping site bottoms to be covered by sands of $0.2 \mathrm{~mm}$ grain diameter.

The bedload transport in the study area is not well recognized. Some estimations of the sediment transport rate were performed for the eastern part of the Gulf of Gdańsk (Kaczmarek et al. 2010; Ostrowski et al. 2010; Chechko et al. 2015). However, all of those studies were focused on the 
Fig. 1 Location of dumping sites in the Gulf of Gdańsk in the Polish sector of the southern Baltic Sea

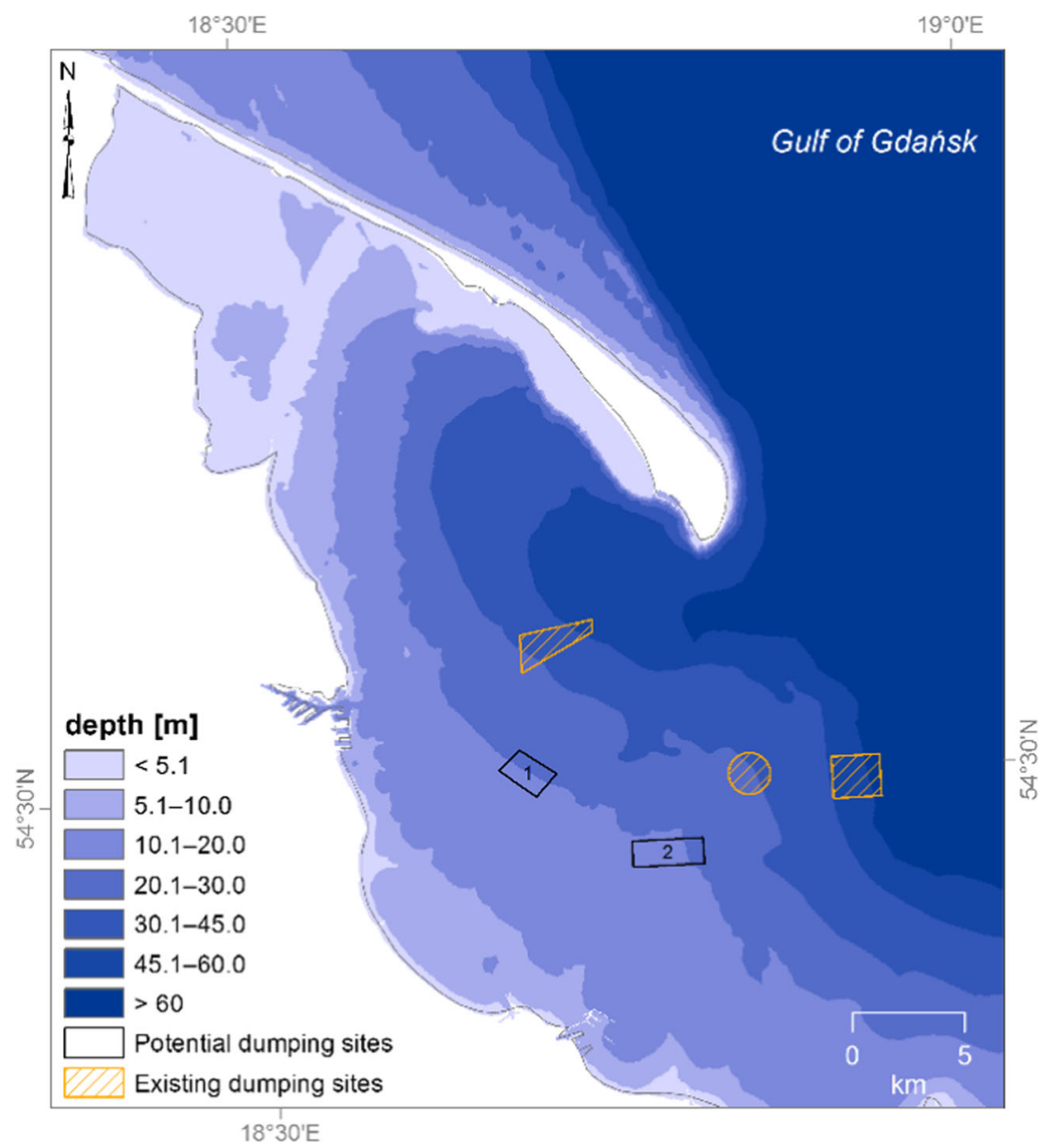

processes taking place at water depths of up to $10-13 \mathrm{~m}$. The occurrence of sediment transport at depths greater than $15 \mathrm{~m}$ is mentioned by Uścinowicz et al. (2014) as well as in some documents related to the commercial projects and unpublished materials.

\subsection{Extreme wind regime in the area}

Analysis of long-term data on wind, wave, and current characteristics in the area of study was conducted using a modeling system developed within the project HIPOCAS, carried out at the Institute of Oceanography, University of Gdańsk

Table 1 Geographic coordinates of the dumping sites' corners

\begin{tabular}{lll}
\hline & Longitude & Latitude \\
\hline Site 1 & $18^{\circ} 40^{\prime} 36^{\prime \prime} \mathrm{E}$ & $54^{\circ} 30^{\prime} 51^{\prime \prime} \mathrm{N}$ \\
& $18^{\circ} 39^{\prime} 42^{\prime \prime} \mathrm{E}$ & $54^{\circ} 30^{\prime} 23^{\prime \prime} \mathrm{N}$ \\
& $18^{\circ} 41^{\prime} 11^{\prime \prime} \mathrm{E}$ & $54^{\circ} 29^{\prime} 43^{\prime \prime} \mathrm{N}$ \\
& $18^{\circ} 42^{\prime} 03^{\prime \prime} \mathrm{E}$ & $54^{\circ} 30^{\prime} 15^{\prime \prime} \mathrm{N}$ \\
Site 2 & $18^{\circ} 45^{\prime} 02^{\prime \prime} \mathrm{E}$ & $54^{\circ} 28^{\prime} 31^{\prime \prime} \mathrm{N}$ \\
& $18^{\circ} 47^{\prime} 56^{\prime \prime} \mathrm{E}$ & $54^{\circ} 28^{\prime} 31^{\prime \prime} \mathrm{N}$ \\
& $18^{\circ} 45^{\prime} 02^{\prime \prime} \mathrm{E}$ & $54^{\circ} 27^{\prime} 55^{\prime \prime} \mathrm{N}$ \\
& $18^{\circ} 47^{\prime} 56^{\prime \prime} \mathrm{E}$ & $54^{\circ} 27^{\prime} 55^{\prime \prime} \mathrm{N}$ \\
\hline
\end{tabular}

(Cieślikiewicz and Paplińska-Swerpel 2008). The most extreme hydrodynamic conditions possible were identified in two different ways.

In scenario 1, an "artificial" storm, wave, and current fields for the entire Baltic Sea were simulated using the WAM, Simulating Waves Nearshore (homepage: http://swanmodel. sourceforge.net/; user guide: http://swanmodel.sourceforge. net/download/zip/swanuse.pdf) (SWAN), and POM models. The model input consisted of eight wind fields, uniform over the entire Baltic Sea, from the W, NW, N, NE, E, SE, S, and SW sectors and the wind speed of $30 \mathrm{~m} \mathrm{~s}^{-1}$. This extreme value of the wind was taken from Cieślikiewicz et al. (2016) where it was estimated based on 138-year NOAA, the Twentieth Century Reanalysis (20CR) (Compo et al. 2011) dataset. The 20CR dataset provides the first estimates of wind direction and speed from 1871 to 2008 at six-hourly temporal and $2^{\circ}$ spatial resolutions. The time series of wind speed at six points selected over the central area of the Baltic Sea were analyzed, and more detailed statistical analysis was performed for wind speed at point $\left(56.1893^{\circ} \mathrm{N}, 18.7500^{\circ} \mathrm{E}\right)$. The maximum wind speed in the 138 -year period considered was $U_{\max }=30.5 \mathrm{~m} \mathrm{~s}^{-1}$ at the WSW direction. Because of this, in modeling of wind wave field for assumed artificial uniform wind fields over the whole Baltic Sea, for all eight cardinal 
and sub-cardinal directions of the wind (W, NW, N, NE, E, SE, S, SW), the wind speed at $10 \mathrm{~m}$ above the sea surface $\left(U_{10}\right)$ of $30 \mathrm{~m} \mathrm{~s}^{-1}$ was applied.

In scenario 2, the 21 historical extreme storms (in the period 1958-2001, details in Cieślikiewicz et al. 2017) were selected, based on wave-field characteristics over the Baltic Sea retrieved from the HIPOCAS database, at the grid point between the two dumping sites considered (see Fig. 2 for details). For both scenarios 1 and 2, the Gulf of Gdańsk wave fields were computed using the SWAN model, with the open boundary conditons derived from the HIPOCAS database. All the simulations were run in a stationary mode to reflect the peak of each storm.

Therefore, a total of 29 most extreme wind regimes of a potential to occur at the two dumping sites designated were considered.

\subsection{Hydrodynamic conditions}

The wind-driven circulation was determined based on the $3 \mathrm{D}$ time-dependent hydrodynamic model (http://model.ocean. univ.gda.pl/indexeng.html) (M3D) (Kowalewski 1997; Jęrasik et al. 2008), which was based on the POM (Blumberg and Mellor 1987). The POM model has been designed to describe ocean hydrodynamics, e.g., upwelling, eddy dynamics, and circulation in the coastal waters, estuaries, as well as whole basins ocean areas.

The 3D velocity fields, the sea surface height, the temperature and salinity were directly solved by the model equations. As the POM model, the M3D was based on the 3D Reynolds-averaged Navier-Stokes equations. It assumed incompressibility and Boussinesq approximation, so that density variations were neglected, except where they were multiplied by gravity in the buoyancy force terms, and the vertical pressure gradient could be obtained from the hydrostatic relation. The eddy viscosity and diffusivity were calculated by the two equation $k-k l$ (MellorYamada level 2.5) turbulence scheme (Mellor and Yamada 1982).

The M3D model was adopted to Baltic conditions (Kowalewski 1997). Due to the open borders of the Gulf of Gdańsk basin, it was necessary to link the Gulf's hydrodynamics with that of the entire Baltic Sea. Thus, the M3D was applied to the Baltic Sea and to the Gulf of Gdańsk subarea, in a form adjusted to the coastal zone conditions. The M3D model, for coastal zone, was developed by two-way dynamic downscaling, allowing to model interdependent fine- and large-scale processes (Jędrasik 2014). Coastal fine mesh of the Gulf of Gdańsk with a horizontal resolution grid of $1 \mathrm{Nm}$ was embedded into a coarser Baltic model of $5 \mathrm{Nm}$ resolution.

The vertical domain in the water column was assumed as $18 \sigma$-layers with narrower layers near the surface and bottom. The thickness of the surface and bottom layer, at each node of the numerical grid, was assumed to be 0.5 and $2 \%$ water depth, respectively, while the thickness in the middle of the profile being $8.3 \%$. A logarithmic boundary layer, using constant bottom roughness $z_{\mathrm{o}}$ of $1 \mathrm{~cm}$, was assumed.

An open boundary is located between the Skagerrak and the Kattegat along the parallel connecting Skagen and Göteborg, where the water exchange with the North Sea takes place. The boundary condition was based on one-hourly observations of sea-level fluctuations at the Göteborg station provided by the Swedish Meteorological and Hydrological Institute (SMHI). A radiation condition based on the
Fig. 2 Configuration of computational grids in the Gulf of Gdańsk used in SWAN and WAM models; parameters of 21 historical storms were adjusted for the grid point (in a circle) located between the two dumping sites

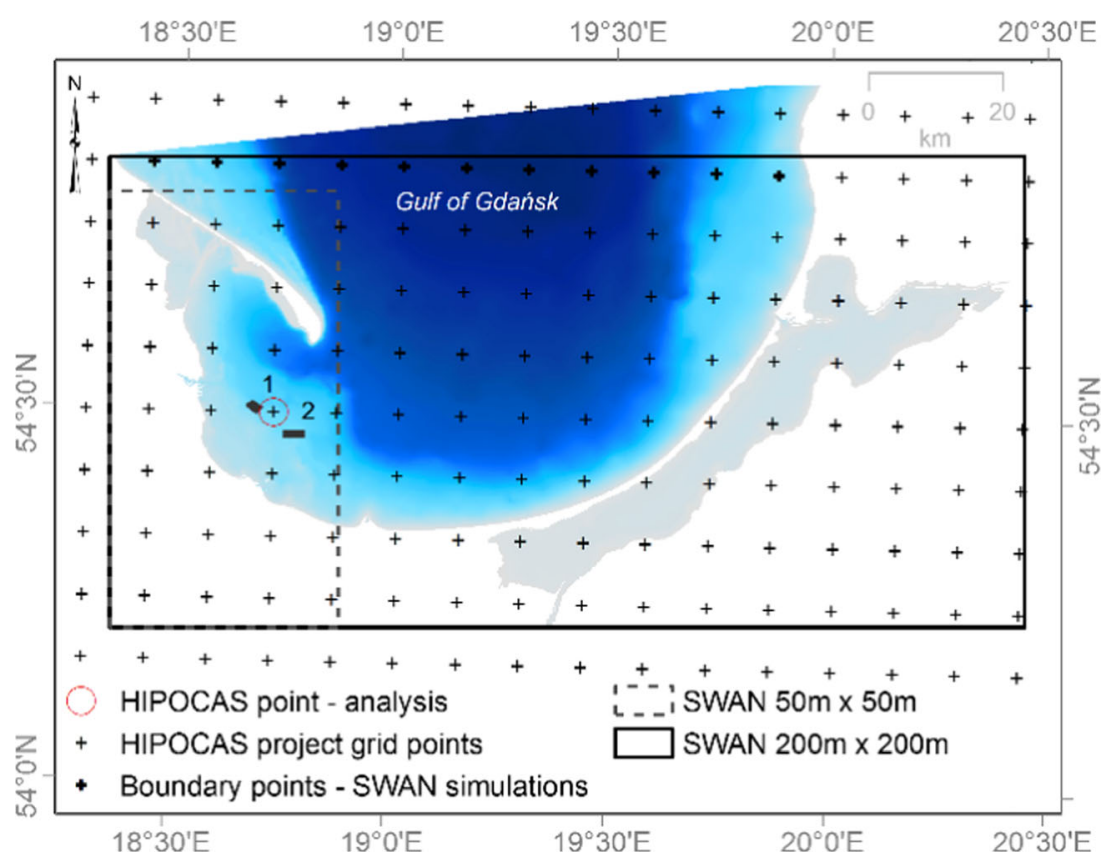


Somerfield's concept for vertically averaged and normal to the boundary plane velocities $V$, was applied (Hedley and Yau 1998):

$V=\frac{C}{h}\left(\eta-\eta^{\prime}\right)$

where $C=\sqrt{g h}$ is the long-wave velocity, $g$ is the gravitational acceleration on Earth, $h$ is depth, and $\eta$ is a free-surface elevation defined as the mean of the surface elevation values for grid points on the open boundary calculated based on the continuity equation. $\eta$ ' denotes a free surface elevation observed in the vicinity of the open boundary. The approach applied resulted in the smallest reflection effects. The salinity of water entering the Baltic Sea via the open boundary was assumed based on monthly mean vertical distributions, as determined by measurements along vertical profiles taken during research cruises in the area of the Skagerrak-Kattegat border. The data were collected in the Baltic Environment Database (BED) of the Baltic Nest Institute (BNI). The water temperature of the inflowing water was assumed to be identical to that in the Kattegat (an assumption of a null gradient perpendicular to the boundary).

The boundary conditions at the free surface were timedependent wind stress and heat fluxes. Atmospheric forcing was performed using the data from the Interdisciplinary Centre for Modeling at the University of Warsaw (ICM), Poland. The surface boundary conditions for heat fluxes were described by bulk formulae analogous to those used in POM and parameterized according to the energy exchange across the sea surface through short- (Krężel 1997) and long-wave radiations, as well as sensible and latent heat transfer (Jędrasik 1997, subsequently revised by Herman et al. 2011). The input of the energy flux component due to a slight surplus of net precipitation, almost balancing evaporation $\left(127 \mathrm{~mm}_{\text {year }}{ }^{-1}\right.$ during the last century, about $20 \%$ of annual net percipitation) (Rutgersson et al. 2002), was omitted. Wind stress drag coefficients were parameterized according to Hellerman and Rosenstein (1983). Following calibration of the model at the $5 \mathrm{Nm}$ grid, the wind stress drag coefficient was eventually assumed to be $2 \times 1 \times 10^{-3}$. Mean monthly discharges into the Baltic Sea of 167 rivers were used at the coastal borders. The relevant data were taken from BED made available by BNI.

Since the Baltic Sea is a non-tidal sea, the hydrodynamic conditions in the Gulf of Gdańsk depend mostly on the atmospheric conditions (winds), the Gulf's bottom topography and inflow of Vistula river waters (see, e.g., Robakiewicz 2000). Annual estuary outflow of the Vistula River equals $1040 \mathrm{~m}^{3} \mathrm{~s}^{-1}$, and an absolute point of flood discharge increases up to $9190 \mathrm{~m}^{3} \mathrm{~s}^{-1}$ (see Fal et al. 1997).

Until the M3D model has become reliable, it had been submitted to basic procedures as calibration (Jeedrasik et al.
2004), verification (Jędrasik 1997), and validation (Jędrasik 2005). Owing to the scarcity of reliable current measurements in the area of interest, the 5-Nm-resolution M3D model has been subject to comprehensive validation against long-term observations of the sea level, salinity, and temperature. The results, concerning the spatial and seasonal variability in shallow and deep coastal waters as well as in the open sea, were examined in relation to the observed values. For details, see Kowalewski (2002), Kannen et al. (2004), Jędrasik (2005), and Jeedrasik et al. (2008). The modeled sea-surface temperature fields were also compared with those obtained from the appropriate satellite SST images, as documented in Jędrasik (2005) and Kowalewski et al. (2009).

The vertical distributions of currents $U(z)$, the bottom current evolution in time, and the bottom current field at the dumping sites were estimated for eight test wind conditions (artificial storms).

The wind-generated wave field was computed using the model WAM cycle 4 (WAMDI Group 1988) implemented within the framework of the project PROZA project (Cieślikiewicz et al. 2014) in the Baltic Sea with the SWAN series III (Booij et al. 1999) being applied to the Gulf of Gdańsk. The models were operating in nested grids: $5 \mathrm{Nm}$ in the Baltic Sea (WAM), $200 \mathrm{~m}$ in the Gulf of Gdańsk (SWAN), and $50 \mathrm{~m}$ in the Puck Bay (SWAN). The simulations produced information on the significant wave height $\left(H_{\mathrm{s}}\right)$, direction of the wave approaching the shore, the mean wave period $(T)$, and the horizontal root-mean-square bottom particle velocity $\left(u_{\mathrm{rms}}\right)$. The spatial extent of the computational grids is presented in Fig. 2.

Previous research performed in the area of interest indicated that the wave-induced currents are negligible (GicGrusza and Dudkowska 2017). This is due to the so-called sheltering effect, caused by Hel Peninsula (Różyński 2010). However, it does not change the fact that a more comprehensive approach to the subject requires taking into account both the wave-induced current velocities and the coupled wave-current model (as it has recently been done, for example, by Franz et al. 2017), which is planned for the authors' future research work.

The three-dimensional current fields together with trajectories of particle tracers spreading out of bottom boundary layer were modeled by Cieślikiewicz et al. (2017). They calculated fields of bottom velocities due to both currents and wind-wave motion. During northerly winds, causing in the Gulf of Gdańsk extreme waves and most significant wind-driven circulation, the wave-induced bottom velocities are greater than velocities due to currents. The current velocities in the bottom layer appeared to be smaller by an order of magnitude than the wave-induced bottom orbital velocities. Namely, during most severe northerly storms analyzed, current bottom velocities ranged about $0.1-0.15 \mathrm{~m} \mathrm{~s}^{-1}$ in the region of two possible dumping sites. The root mean square of wave induced near- 
seabed velocities $\left(u_{\mathrm{rms}}\right)$ reached the values of up to $0.5 \mathrm{~m} \mathrm{~s}^{-1}$ over site 1 and ranged between 0.5 and $0.8 \mathrm{~m} \mathrm{~s}^{-1}$ over site 2 . During most severe northerly storms analyzed in Cieślikiewicz et al. (2017), the maximum bottom current velocities of up to $0.3 \mathrm{~m} \mathrm{~s}^{-1}$ were computed by M3D along the Hel Peninsula on its northern (open sea) side. SWAN modeled the maximum wind wave bottom orbital velocity values $u_{\mathrm{rms}}$ of up to $1.4 \mathrm{~m} \mathrm{~s}^{-1}$, in the narrow strip adjacent to the Vistula Sandbar along the Gulf's south-eastern coast.

\subsection{Bedload transport}

The bedload transport under extreme hydrodynamic conditions was estimated (Eq. (10)), based on data produced by hydrodynamic modeling. The following input data were used:

- The shear velocity $\left(u_{*}\right)$ calculated based on vertical profile of velocity below the $z$-level of $15 \mathrm{~m}$ (from the M3D model, $1 \mathrm{Nm}$ grid resolution) according to the law of the wall (Eq. (2)) to calculate the shear stress $\left(\tau_{\mathrm{c}}\right)$ in the presence of currents (Eq. (3)),

- The average bottom orbital velocity $u_{\mathrm{rms}}$ (from the windgenerated wave model SWAN, $50 \mathrm{~m}$ grid resolution) to calculate the shear stress $\tau_{\mathrm{w}}$ in the presence of waves (Eq. (4)),

- $\quad$ The mean wave period $T$ (from the wind-generated wave model SWAN, $50 \mathrm{~m}$ grid resolution), to calculate the friction factor $f_{\mathrm{w}}$ (Eq. (5)),

- The median of grain size $D_{50}$ and the sediment density $\rho_{\mathrm{s}}$ to calculate the critical shear stress for bedload transport $\tau_{\mathrm{cr}}$, estimated based on the Shields curve (Eq. (7)).

In addition, the critical velocities for bedload transport, the single grain movement $u_{\text {cr }}^{\prime}$, and the sheet flow $u^{\prime \prime}{ }_{\text {cr }}$ were calculated based on the wave period and the friction factor (Eqs. (8) and (9)).

The logarithmic current velocity vertical profile above the seabed (Soulsby 1997) is given by:

$U(z)=\frac{u *}{\kappa} \ln \left(\frac{z}{z_{0}}\right)$

where $\kappa=0.4$ (von Karman's constant).

The bottom shear stress in the presence of currents (Soulsby 1997) is:

$\tau_{\mathrm{c}}=\rho u_{*}^{2}$

The bottom shear stress in the presence of waves (Soulsby 1997) is:

$\tau_{\mathrm{w}}=0.5 \rho f_{\mathrm{w}} u_{\mathrm{rms}}^{2}$
The friction factor (Soulsby 1997) is:

$\ln f_{\mathrm{w}}=-5.977+5.213 r^{-0.19}$

where $r=\frac{u_{b} T}{2 \pi k_{\mathrm{s}}} ; k_{\mathrm{s}}$ is the roughness coefficient; and $u_{\mathrm{b}}$ is assumed as $\sqrt{2} u_{\text {rms. }}$.

The bottom shear stress in the presence of waves and currents (Wu and Lin 2012) is calculated as

$\tau_{\mathrm{cw}}=\left(\tau_{\mathrm{c}}^{2}+\tau_{\mathrm{w}}^{2}+\tau_{\mathrm{c}} \tau_{\mathrm{w}} \cos \alpha\right)^{0.5}$

where $\alpha$ is the angle between the near-bottom current direction and that of the orbital velocity.

The critical shear stress for bedload transport, estimated based on the Shields curve (Soulsby 1997) is:

$\tau_{\mathrm{cr}}=\left\{0.3 /\left(1+1.2 D^{*}\right)+0.055\left[1-\exp \left(-0.02 D^{*}\right)\right]\right\}\left(\varrho_{\mathrm{s}}-\varrho\right) g D_{50}$

$D^{*}=D_{50}\left[g\left(\frac{\varrho_{\mathrm{s}}}{\varrho}-1\right) \nu^{-2}\right]^{1 / 3}$

where $\rho_{\mathrm{s}}=2650 \mathrm{~kg} \mathrm{~m}^{-3}$ and $\rho=1004 \mathrm{~kg} \mathrm{~m}^{-3}$ are densities of sediment and water, respectively; $\nu$ is the kinematic viscosity of the fluid.

This value additionally allows to obtain the critical velocity for bedload transport (Soulsby 1997):

$u_{\mathrm{cr}}^{\prime}=\left(\frac{2 \tau_{c r}}{\varrho f_{\mathrm{w}}}\right)^{0.5}$

The parameter $u_{\text {cr }}^{\prime}$ represents the threshold bottom orbital velocity and shear velocity of sediment motion for the onset of single grain movement. The critical velocity of sheet flow is given by the empirical equation of Sawamoto and Yamashita (1987):

$u_{\mathrm{cr}}^{\prime \prime}=6\left[\left(\frac{\varrho_{\mathrm{s}}}{\varrho}-1\right) g D_{50}\right]^{0.5} D_{50}^{-1 / 3} \delta^{1 / 3}$

where $\delta=v^{0.5} T^{0.5} \pi^{-1}$.

The volumetric bedload transport (Meyer-Peter and Müller 1948 ) is the sediment volume transported in $1 \mathrm{~s}$ through unit width $\left(\mathrm{m}^{2} \mathrm{~s}^{-1}\right.$ ) (see also Dudkowska and Gic-Grusza 2017; Gic-Grusza and Dudkowska 2017).

$Q=3.97\left(\left(\tau_{\mathrm{cw}}-\tau_{\mathrm{cr}}\right)\left(g\left(\varrho_{\mathrm{s}}-\varrho\right) D_{50}\right)^{-1}\right)^{3 / 2}\left(\left(\frac{\varrho_{\mathrm{s}}}{\varrho}-1\right) g D_{50}{ }^{3}\right)^{0.5}$ 


\section{Results}

The wind-generated wave fields were computed with a set of nested WAM and SWAN models for all the 29 test cases. Simulations involving the wind speed of $30 \mathrm{~m} \mathrm{~s}^{-1}$ blowing from the eight cardinal directions (artificial storms) showed the largest wave parameters to occur for the northern-sector winds (N, NE, and NW). In these situations, the significant wave height, wave period, and bottom orbital velocity were in excess of $18 \mathrm{~m}, 15 \mathrm{~s}$ and $2.5 \mathrm{~m} \mathrm{~s}^{-1}$, respectively. These were the maximum values in the Gulf of Gdańsk.

The exact values of wave parameters at dumping sites 1 and 2 are shown in Tables 2 and 3. The highest significant wave height $\left(H_{\mathrm{s}}\right)$, wave period $(T)$, and bottom orbital velocity $\left(u_{\mathrm{b}}\right)$ occurred at the northern-sector (NE) winds: $H_{\mathrm{s}}=6.5 \mathrm{~m}$ (site 1), $7.8 \mathrm{~m}$ (site 2); $T=9.6 \mathrm{~s}$ (site 1 ), $10.5 \mathrm{~s}$ (site 2); $u_{b}=$ $1.25 \mathrm{~m} \mathrm{~s}^{-1}$ (site 1), and $1.53 \mathrm{~m} \mathrm{~s}^{-1}$ (site 2).

The lowest values of those parameters coincided with the southern-sector (SW) winds: $H_{\mathrm{s}}=2.2 \mathrm{~m}$ (site 1), $2.5 \mathrm{~m}$ (site 2); $T=4.2 \mathrm{~s}$ (site 1 ), $4.5 \mathrm{~s}$ (site 2); and $u_{\mathrm{b}}=0.1 \mathrm{~m} \mathrm{~s}^{-1}$ (site 1), $0.12 \mathrm{~m} \mathrm{~s}^{-1}$ (site 2).

Simulations involving the 21 historical storms showed, for the Gulf of Gdańsk (on the northern border of the Gulf) and the vicinity of dumping sites, the maximum significant wave height to be 8.5 and approximately $3 \mathrm{~m}$, respectively; the maximum wave period to be 14 and about $6 \mathrm{~s}$, respectively; and the maximum bottom orbital velocity to be 1.6 and about $0.5 \mathrm{~m} \mathrm{~s}^{-1}$, respectively.
It can be concluded, based on the results of simulations for all the conditions analyzed, that the velocity due to wave action near the bottom, crucial for the sediment transport, is higher at dumping site 2 than at site 1, except for $\mathrm{S}$ and $\mathrm{SE}$ winds.

Three-dimensional time-invariant wind-induced current fields were calculated with the M3D model for each of the eight uniform wind test cases (artificial storms). Vertical profiles of current velocity at the two dumping sites for these test cases are shown in Fig. 3. For the strongest currents (generated by the $\mathrm{SE}, \mathrm{E}$, and $\mathrm{S}$ winds), the surface velocities reach 1-1.4 and $1.3-1.6 \mathrm{~m} \mathrm{~s}^{-1}$ at sites 1 and 2, respectively. The corresponding bottom current velocities are $0.15-0.17$ and 0.2 $0.24 \mathrm{~m} \mathrm{~s}^{-1}$ at sites 1 and 2, respectively. The velocities of surface currents generated by winds from the western and northern sectors (SW, W, NW, N, and NE) are 0.6-1 and $0.7-1.1 \mathrm{~m} \mathrm{~s}^{-1}$ at sites 1 and 2, respectively, whereas the velocities of bottom currents are $0.05-0.015$ and $0.07-$ $0.015 \mathrm{~m} \mathrm{~s}^{-1}$ at sites 1 and 2, respectively. The corresponding shear velocity, as calculated with Eq. (1), ranges within $0.001-$ $0.01 \mathrm{~m} \mathrm{~s}^{-1}$ (Tables 2 and 3), the maximum shear velocity being generated by the south-easterly winds (SE, E, and S).

The friction factor (Eq. (5)) range is $0.01-0.02$, based on the maximum bottom orbital velocity and wave period. The critical velocities for the onset of sediment movement $u_{\text {cr }}^{\prime}$ (Eq. (8)) and for the onset of the sheet flow $u_{\text {cr }}^{\prime \prime}$ (Eq. (8)) estimated for the wave fields analyzed are $u_{\text {cr }}^{\prime} \in(0.13$, $0.22) \mathrm{m} \mathrm{s}^{-1}$ and $u_{\text {cr }}^{\prime \prime} \in(0.5,0.66) \mathrm{m} \mathrm{s}^{-1}$.

Table 2 Values of parameters affecting bedload transport at site 1

\begin{tabular}{|c|c|c|c|c|c|c|c|c|c|}
\hline \multirow[t]{2}{*}{ Site 1} & \multirow[t]{2}{*}{ Data source } & \multicolumn{8}{|c|}{$30 \mathrm{~m} \mathrm{~s}^{-1}$ wind } \\
\hline & & W & SW & $\mathrm{S}$ & SE & $\mathrm{E}$ & $\mathrm{NE}$ & $\mathrm{N}$ & NW \\
\hline Wind direction $\left(^{\circ}\right)$ & & $0 / 360$ & 45 & 90 & 135 & 180 & 225 & 270 & 315 \\
\hline$H_{\mathrm{s}}(\mathrm{m})$ & SWAN & 2.4 & 2.2 & 2.8 & 4.1 & 5.1 & 6.5 & 6.3 & 3.2 \\
\hline$T(\mathrm{~s})$ & SWAN & 4.4 & 4.2 & 4.9 & 6.3 & 7.6 & 9.5 & 9.6 & 5.4 \\
\hline$u_{\mathrm{b}}\left(\mathrm{m} \mathrm{s}^{-1}\right)$ & SWAN & 0.13 & 0.10 & 0.22 & 0.53 & 0.83 & 1.25 & 1.23 & 0.37 \\
\hline$u_{\mathrm{rms}}\left(\mathrm{m} \mathrm{s}^{-1}\right)$ & SWAN & 0.09 & 0.07 & 0.15 & 0.38 & 0.59 & 0.88 & 0.87 & 0.26 \\
\hline Wave direction $\left(^{\circ}\right)$ & SWAN & 347 & 54 & 119 & 174 & 206 & 224 & 235 & 281 \\
\hline$\tau_{\mathrm{w}}\left(\mathrm{N} \mathrm{m}^{-2}\right)$ & Eq. (3) & 0.08 & 0.05 & 0.17 & 0.73 & 1.51 & 2.98 & 2.90 & 0.41 \\
\hline$u_{*}\left(\mathrm{~m} \mathrm{~s}^{-1}\right)$ & Eq. (1) & 0.005 & 0.004 & 0.008 & 0.012 & 0.010 & 0.005 & 0.001 & 0.004 \\
\hline$U_{\mathrm{b}}\left(\mathrm{m} \mathrm{s}^{-1}\right)$ & M3D & 0.14 & 0.15 & 0.14 & 0.18 & 0.18 & 0.16 & 0.08 & 0.07 \\
\hline Bottom current direction $\left(^{\circ}\right)$ & M3D & 215 & 219 & 150 & 114 & 79 & 31 & 24 & 203 \\
\hline$\tau_{\mathrm{c}}\left(\mathrm{N} \mathrm{m}^{-2}\right)$ & Eq. (2) & 0.03 & 0.02 & 0.07 & 0.15 & 0.10 & 0.03 & 0.00 & 0.01 \\
\hline$\tau_{\mathrm{cw}}\left(\mathrm{N} \mathrm{m}^{-2}\right)$ & Eq. (5) & 0.07 & 0.04 & 0.21 & 0.78 & 1.49 & 2.97 & 2.90 & 0.41 \\
\hline$f_{\mathrm{w}}$ & Eq. (4) & 0.018 & 0.021 & 0.015 & 0.010 & 0.009 & 0.008 & 0.008 & 0.012 \\
\hline$u_{\mathrm{cr}}^{\prime}\left(\mathrm{m} \mathrm{s}^{-1}\right)$ & Eq. (7) & 0.14 & 0.13 & 0.16 & 0.18 & 0.20 & 0.21 & 0.21 & 0.17 \\
\hline$u_{\mathrm{cr}}^{\prime \prime}\left(\mathrm{m} \mathrm{s}^{-1}\right)$ & Eq. (8) & 0.52 & 0.51 & 0.53 & 0.55 & 0.57 & 0.59 & 0.59 & 0.54 \\
\hline$Q_{\mathrm{v}}\left(\mathrm{m}^{2} \mathrm{~s}^{-1}\right) \times 10^{-5}$ & Eq. (9) & 0.0 & 0.0 & 0.0 & 0.4 & 1.4 & 4.0 & 3.8 & 0.2 \\
\hline
\end{tabular}

Results of calculations for eight test cases: uniform wind $\left(30 \mathrm{~m} \mathrm{~s}^{-1}\right)$ over the entire Baltic Sea from cardinal directions 
Table 3 Values of parameters affecting bedload transport at site 2

\begin{tabular}{|c|c|c|c|c|c|c|c|c|c|}
\hline \multirow[t]{2}{*}{ Site 2} & \multirow[t]{2}{*}{ Data source } & \multicolumn{8}{|c|}{$30 \mathrm{~m} \mathrm{~s}^{-1}$ wind } \\
\hline & & W & SW & $\mathrm{S}$ & SE & $\mathrm{E}$ & $\mathrm{NE}$ & $\mathrm{N}$ & NW \\
\hline Wind direction $\left({ }^{\circ}\right)$ & & $0 / 360$ & 45 & 90 & 135 & 180 & 225 & 270 & 315 \\
\hline$H_{\mathrm{s}}(\mathrm{m})$ & SWAN & 3.3 & 2.5 & 2.7 & 3.8 & 6.9 & 7.7 & 7.8 & 6.0 \\
\hline$T(\mathrm{~s})$ & SWAN & 5.3 & 4.5 & 4.8 & 6.0 & 8.6 & 10.1 & 10.5 & 8.8 \\
\hline$u_{\mathrm{b}}\left(\mathrm{m} \mathrm{s}^{-1}\right)$ & SWAN & 0.35 & 0.12 & 0.17 & 0.44 & 1.18 & 1.48 & 1.53 & 1.07 \\
\hline$u_{\mathrm{rms}}\left(\mathrm{m} \mathrm{s}^{-1}\right)$ & SWAN & 0.24 & 0.08 & 0.12 & 0.31 & 0.84 & 1.05 & 1.08 & 0.76 \\
\hline Wave direction $\left(^{\circ}\right)$ & SWAN & 329 & 39 & 112 & 169 & 218 & 228 & 234 & 256 \\
\hline$\tau_{\mathrm{w}}\left(\mathrm{N} \mathrm{m}^{-2}\right)$ & Eq. (3) & 0.37 & 0.07 & 0.12 & 0.55 & 2.80 & 4.04 & 4.23 & 2.32 \\
\hline$u_{*}\left(\mathrm{~m} \mathrm{~s}^{-1}\right)$ & Eq. (1) & 0.003 & 0.001 & 0.011 & 0.013 & 0.012 & 0.002 & 0.004 & 0.005 \\
\hline$U_{\mathrm{b}}\left(\mathrm{m} \mathrm{s}^{-1}\right)$ & M3D & 0.10 & 0.04 & 0.20 & 0.23 & 0.22 & 0.12 & 0.09 & 0.06 \\
\hline Bottom current direction $\left({ }^{\circ}\right)$ & M3D & 236 & 165 & 151 & 138 & 115 & 53 & 357 & 287 \\
\hline$\tau_{\mathrm{c}}\left(\mathrm{N} \mathrm{m}^{-2}\right)$ & Eq. (2) & 0.01 & 0.00 & 0.11 & 0.18 & 0.15 & 0.01 & 0.01 & 0.03 \\
\hline$\tau_{\mathrm{cw}}\left(\mathrm{N} \mathrm{m}^{-2}\right)$ & Eq. (5) & 0.37 & 0.07 & 0.19 & 0.65 & 2.79 & 4.04 & 4.23 & 2.33 \\
\hline$f_{\mathrm{w}}$ & Eq. (4) & 0.012 & 0.019 & 0.016 & 0.011 & 0.008 & 0.007 & 0.007 & 0.008 \\
\hline$u_{\mathrm{cr}}^{\prime}\left(\mathrm{m} \mathrm{s}^{-1}\right)$ & Eq. (7) & 0.17 & 0.14 & 0.15 & 0.18 & 0.21 & 0.22 & 0.22 & 0.21 \\
\hline$u_{\mathrm{cr}}^{\prime \prime}\left(\mathrm{m} \mathrm{s}^{-1}\right)$ & Eq. (8) & 0.53 & 0.52 & 0.52 & 0.55 & 0.58 & 0.59 & 0.60 & 0.58 \\
\hline$Q_{\mathrm{v}}\left(\mathrm{m}^{2} \mathrm{~s}^{-1}\right) \times 10^{-5}$ & Eq. (9) & 0.14 & 0.00 & 0.01 & 0.28 & 3.55 & 6.19 & 6.64 & 2.66 \\
\hline
\end{tabular}

Results of calculations for eight test cases: uniform wind $\left(30 \mathrm{~m} \mathrm{~s}^{-1}\right)$ over the entire Baltic Sea from cardinal directions

The parameters affecting the bottom shear stress produced by wave-induced currents proved to be associated with the wave-driven average bottom orbital velocity $\left(u_{\mathrm{rms}}\right)$ and with the wind-driven current shear velocity $(u *)$. For all the eight test cases (artificial storms), $u_{\mathrm{rms}}$ is $1-2$ orders of magnitude higher then $u_{*}$. It follows then that the bottom shear stress is mainly generated by waves, the wind-driven currents modifying it only slightly. The calculations performed (Tables 2 and 3 ) indicate that the wave-induced shear stress at sites 1 and 2 ranges within $\tau_{\mathrm{w}} \in(0.05,4.2) \mathrm{N} \mathrm{m}^{-2}$. At the same time, the shear stress generated by wave-induced currents covers almost the same range, $\tau_{\mathrm{wc}} \in(0.04,4.2) \mathrm{N} \mathrm{m}^{-2}$. The influence of wind-driven currents depends on the wind direction. The weighted difference $\left(\tau_{\mathrm{w}}-\tau_{\mathrm{wc}}\right) / \tau_{\mathrm{w}}$ is at its lowest for the northerly winds (N, NE, and NW), about $\pm 0.5 \%$ at both sites. The difference is at its highest for the southerly wind (S): -23 and $-63 \%$ at sites 1 and 2, respectively. However, the values of shear stress in such cases are low (about ten times lower than those for the northerlies); moreover, storms from the southern sector in the area are very rare.

Thus, based on the eight test cases with a uniform wind field, we showed that the impact of wind-induced currents on the bottom shear stress is insignificant (Fig. 3), and that it can be ignored in calculations of sediment transport. The results obtained concern the magnitude of transport induced by wave action. With this assumption, we computed the magnitude of
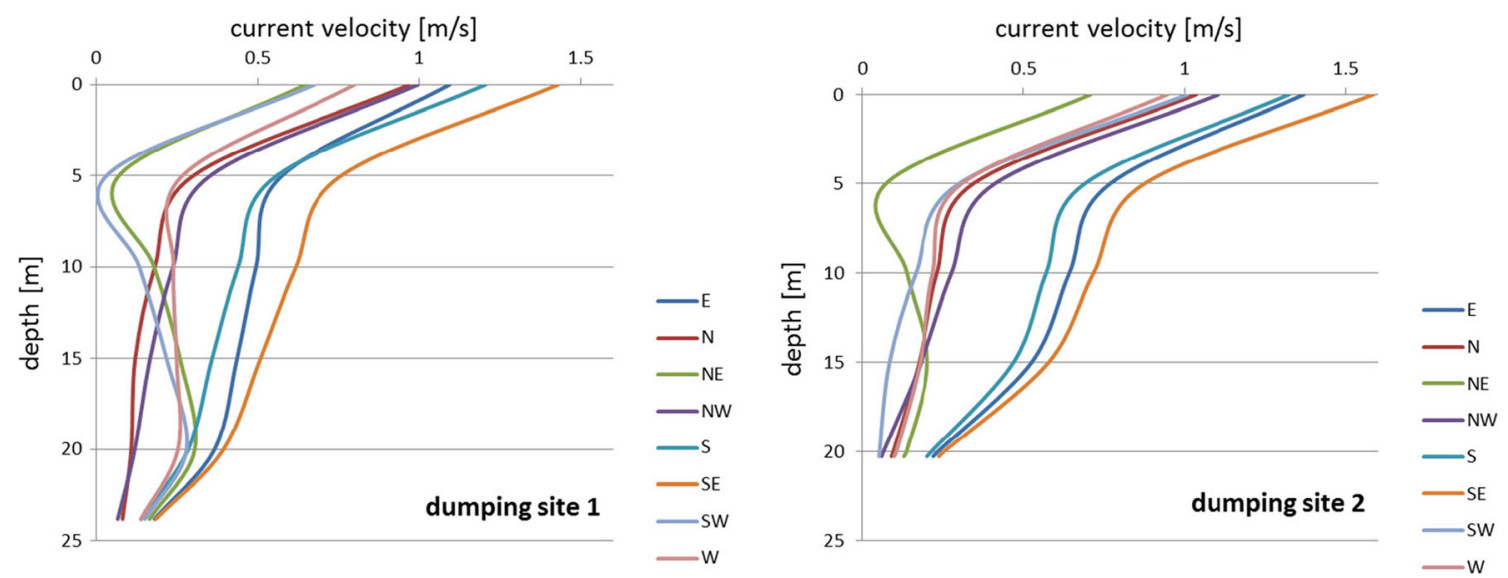

Fig. 3 Vertical profiles of current velocity at the dumping sites calculated by M3D model, forced by $30 \mathrm{~m} \mathrm{~s}^{-1}$ wind from cardinal directions, uniform over the entire Baltic Sea (eight test cases) 


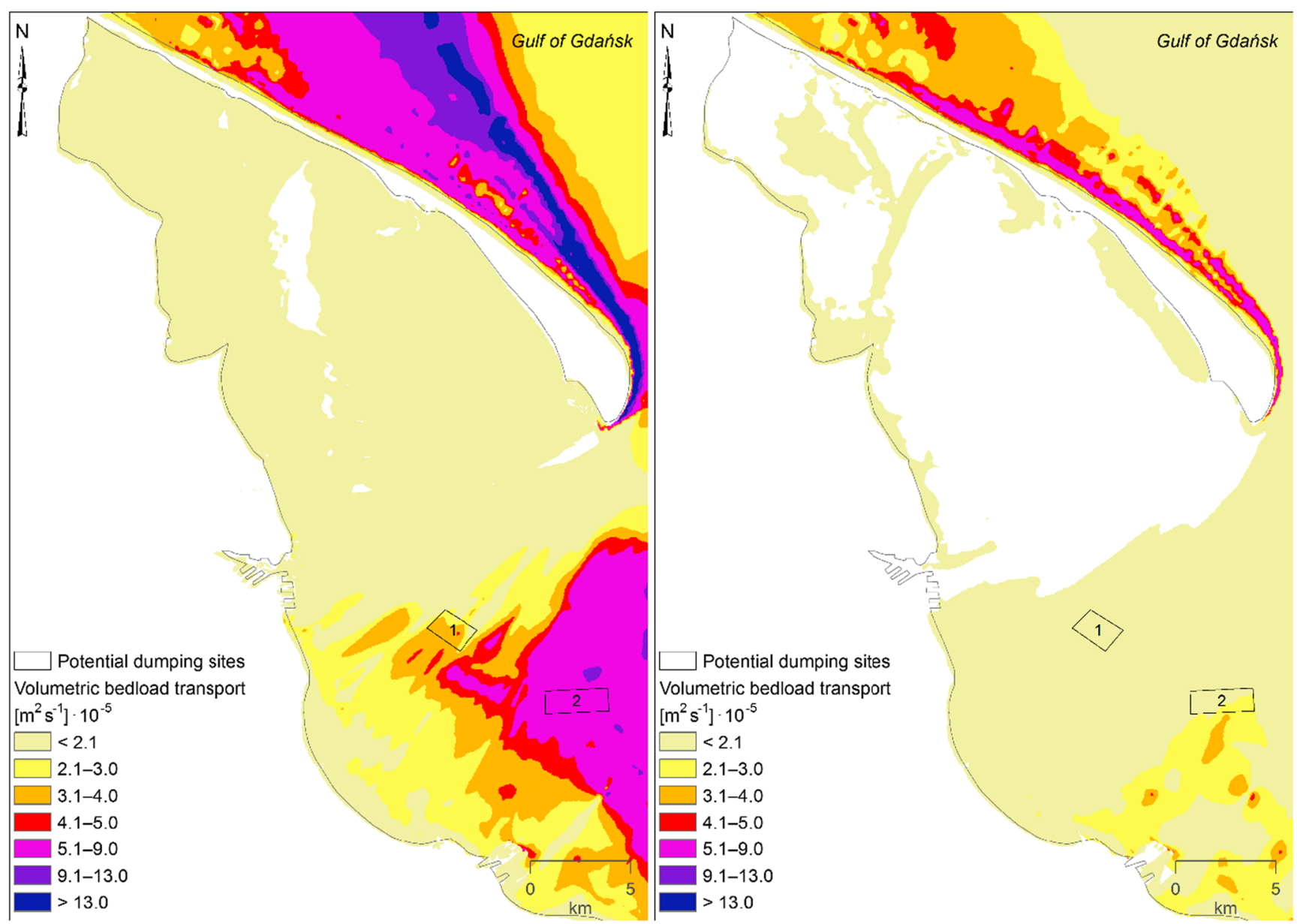

Fig. 4 The volumetric bedload transport for the northern-sector $30 \mathrm{~m} \mathrm{~s}^{-1}$ wind (left) and for the historical storm of November 1988 (right)

sediment transport for all the 29 test cases. Under the most extreme wind conditions (artificial storms), a substantial bedload volumetric transport $\left(Q_{\mathrm{v}} \sim 10^{-5} \mathrm{~m}^{2} \mathrm{~s}^{-1}\right)$ at sites 1 and 2 occurred at wind directions E, NE, N, and NW (Tables 1 and 2); for every wind direction, the transport is larger at site 2 than at site 1 .

All the 21 historical storms considered showed similar characteristics on the northern border of the Gulf of Gdańsk, i.e., the maximum significant wave height $H_{\mathrm{s}} \in(5.33,8.53)$, and the prevalent wave direction being from northern sectors. In the case of the heaviest storm (November 1988), the sediment transport, $Q_{v}=2.1 \times 10^{-5} \mathrm{~m}^{2} \mathrm{~s}^{-1}$ occurred at site 2 , the transport at site 1 being ten times lower.

It was assessed within this study if the change in bottom topography, caused by dumping of dredged material in deposition sites 1 and 2, may alter the hydrodynamic regime during most severe storms. It appeared the change of water depth over the deposition sites of order of $1 \mathrm{~m}$ does not change the wind wave and current fields. The $3 \mathrm{~m}$ decrease of water depth, over deposition sites, which actually exceeds the possible reduction of water depth estimated based on expected total volume of dredged material, was also examined in terms of potential change of hydrodynamic conditions in the study area. It was found that that $3 \mathrm{~m}$ water depth decrease might result in $10 \%$ change of significant wave height in the wave shadow area directly behind the deposition sites. The change in the volumetric bedload transport caused by this variation of hydrodynamic conditions is at most of order of $10^{-6} \mathrm{~m}^{2} \mathrm{~s}^{-1}$ and thus may be neglected.

The spatial distribution of sediment transport in the case of the uniform $30 \mathrm{~m} \mathrm{~s}^{-1}$ northerly storm and in the case of the most extreme historical storm (November 1988) is shown in Fig. 4.

\section{Discussion and conclusions}

The decision-making process associated with the designation of marine dumping sites for locations for dredged material should involve, in addition to numerous environmental issues, two important depth-related aspects: the material should be deposited deep enough to prevent dispersion of the dumped material and shallow enough to allow it to be re-used. We presented the methodology which can aid in such decisionmaking. To designate the best site for dumping, windgenerated wave field and wind-induced current field under 
the most extreme conditions possible should be considered. Subsequently, the near-bottom orbital velocities under wave and current action as well as critical velocities for the relevant environmental conditions should be calculated for the potential location. If the critical bedload transport velocity is exceeded, the volume of sediment transported should be computed based on the total shear stress. The result should be examined in light of the total volume of material to be dumped.

We used the M3D hydrodynamic model of the Baltic Sea and the Gulf of Gdańsk to calculate the velocity of windinduced currents and the WAM model for the entire Baltic Sea with downscaling of SWAN at the Gulf of Gdańsk to determine near-bottom orbital velocity under wind-generated waves. For the two potential dumping grounds in the Gulf of Gdańsk, we showed the critical bottom orbital velocities for bedload transport and for sheet flow to be exceeded during extreme storms. For the most probable storms (wind from northern sectors: NW, N, and NE), the near-bottom orbital velocity value is crucial, whereas the impact of windinduced currents can be ignored. Subsequently, we calculated the total bedload transport resulting from wave-induced and current-induced shear stress. During an extreme storm, the volumetric bedload transport is on the order of $10^{-5} \mathrm{~m}^{2} \mathrm{~s}^{-1}$ at one of the sites considered. This value, although noticeable, is insignificant compared with the volume of the material dumped. Based on these results, we conclude that dumping sites in the western Gulf of Gdańsk might be located at depths of 15-20 m. However, a more accurate quantitative estimate of the sediment transport in the study area requires more comprehensive in situ measurements and will be the subject of further investigation.

Funding information A part of the work has been conducted within the project PROZA, partially funded by the European Union under the Innovative Economy Programme contract No. POIG.010301. A part of this research has been also supported by the Polish National Centre for Research and Development project "Development of a predictive model of morphodynamic changes in the coastal zone" (Grant No. DEC-2011/ 01/D/ST10/0766).

Open Access This article is distributed under the terms of the Creative Commons Attribution 4.0 International License (http:// creativecommons.org/licenses/by/4.0/), which permits unrestricted use, distribution, and reproduction in any medium, provided you give appropriate credit to the original author(s) and the source, provide a link to the Creative Commons license, and indicate if changes were made.

\section{References}

Blumberg AF, Mellor GL (1987) A description of a three-dimensional coastal ocean circulation model. In: Heaps N (ed) Three dimensional coastal ocean models 4. American Geophysical Union, Washington, DC, p 208
Booij N, Ris RC, Holthuijsen LH (1999) A third-generation wave model for coastal regions. J Geophys Res 104(C4):7649-7666

Chechko V, Sokolov A, Chubarenko B, Dikii D, Topchaya V (2015) Dynamics of sediments disposed in the marine coastal zone near the Vistula Lagoon inlet, south-eastern part of the Baltic Sea. Baltica 28:189-199

Christiansen C, Edelvang K, Emeis K, Graf G, Jähmlich S, Kozuch J, Laima M, Leipe T, Löffler A, Lund-Hansen LC, Miltner A, Pazdro K, Pempkowiak J, Shimmield G, Shimmield T, Smith J, Voss M, Witt G (2002) Material transport from the nearshore to the basinal environment in the southern Baltic Sea: I. Process and mass estimates. J Mar Syst 35:133-150

Cieślikiewicz W, Paplińska-Swerpel B (2008) A 44-year hindcast of wind wave fields over the Baltic Sea. Coast Eng 55:894-905

Cieślikiewicz W, Dudkowska A, Janowczyk R, Roščinski V, Roziewski Sz, Badur J (2014) Wind wave modelling over the Baltic Sea using WAM model and the coupled ocean circulation-wave POM model. In: Proc 34th Int Conf on Coastal Engineering, Seoul, Korea, 15-20 June 2014 (ICCE 2014), posters 42. https://doi.org/10.9753/icce. v34.posters. 42

Cieślikiewicz W, Dudkowska A, Gic-Grusza G (2016) Port of Gdańsk and port of Gdynia's exposure to threats resulting from storm extremes. JPSRA 7:29-36

Cieślikiewicz W, Dudkowska A, Gic-Grusza G, Jędrasik J (2017) Extreme bottom velocities induced by wind wave and currents in the Gulf of Gdańsk. Ocean Dyn 67(11):1461-1480

Compo GP, Whitaker JS, Sardeshmukh PD, Matsui N, Allan RJ, Yin X, Gleason BE Jr, Vose RS, Rutledge G, Bessemoulin P, Bronnimann S, Brunet M, Crouthamel RI, Grant AN, Groisman PY, Jones PD, Kruk MC, Kruger AC, Marshall GJ, Maugeri M, Mok HY, Nordli $\varnothing$, Ross T, Trigo R, Wang X, Woodruff SD, Worley S (2011) Review article - the twentieth century reanalysis project. Q J R Meteorol Soc 137:1-28

Dudkowska A, Gic-Grusza G (2017) Wave-induced bedload transportsouthern Baltic coastal zone study. Andean Geol 23:1-14

Emeis K, Christiansen C, Edelvang K, Jähmlich S, Kozuch J, Laima M, Leipe T, Löffler A, Lund-Hansen LC, Miltner A, Pazdro K, Pempkowiak J, Pollehne F, Shimmield T, Smith J, Voss M, Witt G (2002) Material transport from the near shore to the basinal environment in the southern Baltic Sea: II. Synthesis of data on origin and properties of material. J Mar Syst 35:151-168

Fal B, Bogdanowicz E, Czernuszenko W, Bobrzyńska I, Koczyńska A, (1997) Characteristic runoffs of the main Polish rivers in the years 1951-1990. Research materials. Series of Hydrology and Oceanology. Institute of Meteorology and Water Management, Warsaw, No. 21, 143 pp (in Polish)

Franz G, Delpey MT, Brito D, Pinto L, Leitão P, Neves R (2017) Modelling of sediment transport and morphological evolution under the combined action of waves and currents. Ocean Sci 13:673-690

Gic-Grusza G, Dudkowska A (2017) Numerical modeling of hydrodynamics and sediment transport - an integrated approach. Ocean Dyn 67:1283-1292

Harff J, Furmanczyk K, Von Storch H (eds) (2017) Coastline changes of the Baltic Sea from south to east, Coastal Research Library, 19th edn. Springer International Publishing, p 388

Hedley M, Yau K (1998) Radiation boundary conditions in numerical modelling. Mon Weather Rev 116:1721-1736

HELCOM (2015) Dataset 1. Deposit of dredged material areas/points 2011-2015

Hellerman S, Rosenstein M (1983) Normal monthly wind stress over the world ocean with error estimates. J Phys Oceanogr 13:1093-1104

Herman A, Jędrasik J, Kowalewski M (2011) Numerical modelling of thermodynamics and dynamics of sea ice in the Baltic Sea. Ocean Sci 7:257-276

Jedrasik J (1997) A model of matter exchange and flow of energy in the Gulf of Gdańsk ecosystem —overview. Ocean Stud 26:3-20 
Jędrasik J (2005) Validation of the hydrodynamic part of the ecohydrodynamic model for the southern Baltic. Oceanologia 47: $1-25$

Jędrasik J (2014) Retrospective modelling and forecasting of the Baltic Sea hydrodynamics. Univ. of Gdańsk Publ., Gdańsk, pp 1-190

Jędrasik J, Swerpel B, Cieślikiewicz W, Kowalewski M, Bradtke K, Jankowski A (2004) 40 years hindcast of the circulation and wave hindcast in the Baltic Sea, Report EU Project HIPOCAS, Project No: EVK2-CT-1999-00038, 9-14

Jędrasik J, Cieślikiewicz W, Kowalewski M, Bradtke K, Jankowski A (2008) 44 years hindcast of the sea level and circulation in the Baltic Sea. Coast Eng 55:849-860

Kaczmarek LM, Ostrowski R, Szmytkiewicz M (2010) Sediment transport issues related to a planned cross-cut through the Vistula Spit, Poland. AHEM 57:119-137

Kannen A, Jędrasik J, Kowalewski M, Ołdakowski B, Nowacki J (2004) Assessing catchment coast interactions for the Bay of Gdansk. In: Schernewski G, Löser N (eds) Managing the Baltic Sea. Schiffahrt, Hamburg, pp 155-165

Kowalewski M (1997) A three-dimensional hydrodynamic model of the Gulf of Gdańsk. Oceanological Studies 26(4):77-98

Kowalewski M (2002) An operational hydrodynamic model of the Gulf of Gdańsk. Research works based on the ICM's UMPL numerical weather prediction system results, Fizyka Atmosfery, Wyd. ICM Warszawa, Poland, pp 109-119

Kowalewski M, Jankowski A, Gajewski J, Piotrowski M, Jędrasik J, Kowalewska M, Ślimak A (2009) Upgrade of existing model M3D_UG, implementation of data assimilation routines in the model M3D, Implementation of assimilation method of the SST rep. ECOOP, Project No. 036355, S5.2.3.6, pp 1-52

Krężel A (1997) A model of solar energy input to the sea surface. Oceanological Studies 26(4):21-34

Kuhrts C, Fennel W, Seifert T (2004) Model studies of transport of sedimentary material in the western Baltic. J Mar Syst 52:167-190

Mellor GL, Yamada T (1982) Development of a turbulence closure model for geophysical fluid problems. Rev Geophys 20:851-875

Meyer-Peter E, Müller R (1948) Formulas for bed-load transport. In: Proceedings of the 2nd meeting, IAHR: 39-64, Stockholm, Sweden

Mojski JE (ed) (1988-1995) Geological map of the Baltic Sea bottom 1: 200000. Polish Geological Institute, Warsaw
Ostrowski R, Pruszak Z, Skaja M, Szmytkiewicz M (2010) Variability of hydrodynamic and lithodynamic coastal processes in the east part of the Gulf of Gdańsk. AHEM 57:139-153

PIG-PIB (2012) Ocena możliwości użycia urobku z robót czerpalnych związanych z modernizacją toru podejściowego do Portu Północnego w ramach projektu "Port Północny - Modernizacja toru podejściowego i falochronu wyspowego". Budowa geologiczna dna w rejonie toru podejściowego do Portu Północnego (in Polish)

Pupienis D, Jankowski A (2006) Modelling of sediment transport in the dumps in the Lihuanian offshore. Proc 9th Marine Geological Conference "The Baltic Sea Geology-9", 27th August-3rd September 2006, poster

Robakiewicz M (2000) Influence of the Gdańsk - east wastewater treatment plant on the coastal zone of the Gulf of Gdańsk - hydrodynamic aspects. Oceanol Stud 29:99-110

Różyński G (2010) Wave climate in the Gulf of Gdańsk vs. open Baltic Sea near Lubiatowo, Poland. AHEM 57:167-176

Rutgersson A, Omstedt A, Räisänen J (2002) Net precipitation over the Baltic Sea during present and future climate conditions. Clim Res 22:27-39

Sawamoto M, Yamashita T (1987) Sediment transport in sheet flow regime. Proc Coastal Sediments 87:415-423

Seifert T, Kayser B (1995) A high resolution spherical grid topography of the Baltic Sea. Meereswissenschaftliche Berichte 9. Institut für Ostsee forschung, Warnemünde, pp 72-88

Soulsby R (1997) Dynamics of marine sands. Thomas Telford Publications, London

Staniszewska M, Boniecka H (2015) The environmental protection aspects of handling dredged material. BMI 30:51-58

Uścinowicz S, Jegliński W, Miotk-Szpiganowicz G, Nowak J, Pączek U, Przezdziecki P, Szefler K, Poręba G (2014) Impact of sand extraction from the bottom of the southern Baltic Sea on the relief and sediments of the seabed. Oceanologia 56:857-880

Van Dolah RF, Calder DR, Knott DM (1984) Effects of dredging and open-water disposal on benthic macroinvertebrates in a South Carolina estuary. Estuaries 7:28-37

WAMDI Group (1988) The WAM model—a Third Generation Ocean Wave Prediction Model. J Phys Oceanogr 18:1775-1810

Wu W, Lin Q (2012) A multiple-sized transport formula for nonuniform sediments under current and waves. Proceedings of 33rd Conference on Coastal Engineering, Santander, Spain 